\title{
Making Wellington: earthquakes, survivors and creating heritage
}

Robert McClean, Senior Heritage Policy Adviser, New Zealand Historic Places Trust Pouhere Taonga (NZHPT)

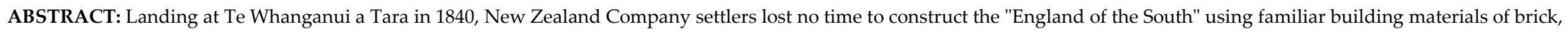

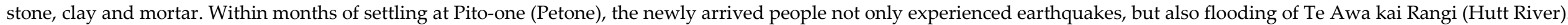
Consequently, the original plan to build the City of Britannia at Pito-one was transferred to Lambton Harbour at Pipitea and Te Aro.

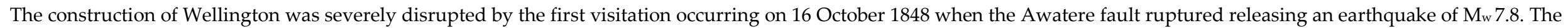

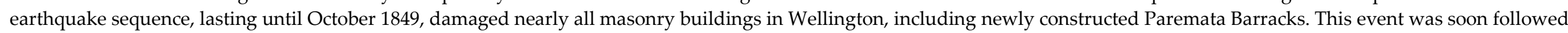
by the 2 nd visitation of 23 January 1855. This time it was a rupture of the Wairarapa fault and a huge 8.2 Mw earthquake lasting until 10 October 1855.

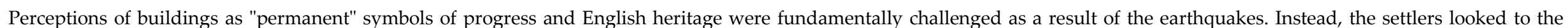

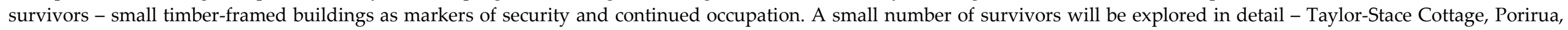

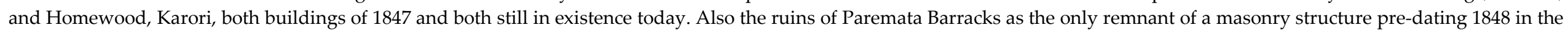

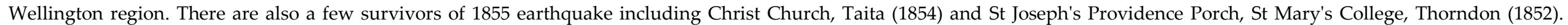

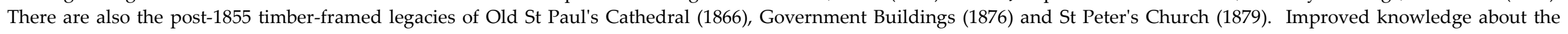

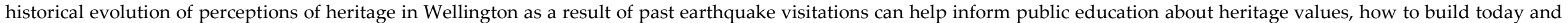
strengthen existing buildings in readiness for future earthquake visitations.

\section{Introduction}

The Canterbury earthquakes of 2010-12 have trigged a re-appraisal of building policy and regulation - both for new buildings and existing buildings. This process is led by the Canterbury Earthquakes Royal Commission and the earthquake-prone policy review of the Building Act 2004. Recalling Wellington's earthquake experience of 1848 and 1855 can also make a valuable contribution towards current building policy and regulation. The Wellington experience took place at the early phase of European settlement and had a formative impact on the life and townscape of early Wellington. This paper reviews the influence of the 1848 and 1855 earthquakes on building design and the construction of Wellington as a "timber town."

Many hundreds of buildings survived the 1848 and 1855 earthquakes with minor damage except for the loss of chimneys. Only a few of these buildings, however, have survived since 1855 . The few remaining pre1855 buildings are a special and unique collection associated with early Wellington history, its people and early building techniques. Homewood (Karori), Taylor-Stace
Cottage (Pāuatahanui), Collet House (Petone), and Christ Church (Taitā) are within the select group of pre-1855 buildings. This group, however, is not definitive and may include other buildings such as Papakōwhai Homestead (Paremata), Harrison Cottage (Glenside), and Fern Hill (Wadestown). Outside of Wellington it includes Dicky Sayer's Slab Whare (Carterton District), Robin Hood Bay Cottage (Marlborough) and St John's at Wakefield. ${ }^{1}$ Each building can "tell a

${ }^{1}$ Homewood, Taylor-Stace Cottage, Collet House, Christ Church, Papakowhai Homestead, Dicky Sayer's Slab 
story" of construction, survival, adaptation and change. They can provide clues to how buildings can meet successive earthquake events and continue to provide a place of safety and shelter.

\section{0 arrival}

Systematic colonisation, as led by the New Zealand Company, was principally concerned with acquiring, purchasing and making land available for settlement. To make this happen, the establishment of urban settlements at key strategic port locations was a critical component. $^{2}$

While the plan for the town of Britannia was drawn up in London in 1839 for "the pakeha dream of little London on the Hutt," 3 it appears that the Company provided little guidance on the type and nature of the buildings that would make up the "principal settlement" of the Company in New Zealand. As commented by John Stacpoole:

Though the New Zealand Company had set out to

Whare, Robin Hood Bay Cottage and St John's at

Wakefield are on the New Zealand Historic Places'

"Register of Historic Places" Harrison Cottage and Fern

Hill are not registered by the NZHPT.

${ }^{2}$ Hamer New Towns in the New World p 253.

${ }^{3}$ McGill Lower Hutt The First Garden p 25. transplant a whole cross-section of society to its settlement, it seems to have paid little attention to architects, a curious omission but one which was not entirely out of character with a body which was more concerned with theory than with practice. ${ }^{4}$

The Company was also not organised enough to construct substantial emigration barracks for settlers arriving at Te Whanganui a Tara in 1840. Consequently, temporary beach-head huts were erected in the area known today as Petone (Pito-one). Henry Petre, arriving on the Oriental on 31 February 1840 recalled:

Our first habitations consisted entirely of very rude huts built by ourselves. At a later period after the arrival of the other emigrant ships, the natives rendered valuable assistance in this sort of work, at which they are very expert. It must be confessed that the huts built by them were much superior to those of our own handywork. Many of them indeed deserved to be called houses and were, when I quitted Port Nicholson, still used by the emigrants of all classes, none of whom it may be safely said suffered any serious inconvenience from the want of more comely dwellings. ${ }^{5}$

The huts were largely made of raupō, timber and other local materials. As Chris Cochran states, the first buildings were "little different from the traditional Māori whare that had

${ }^{4}$ Stacpoole Colonial Architecture p 37.

${ }^{5}$ Petre An Account of the Settlements of the New Zealand Company p 11. been brought to a high level of usefulness by the indigenous people." ${ }^{6}$ Cochran described the dwellings as:

Timber in the round for a frame, tied together with a braid of flax, and the whole of the walls and roof thatched with raupo. If doors and windows had been brought out, these may have been installed for later removal to a more permanent dwelling. ${ }^{7}$

Life in the late summer of 1840 at $\mathrm{Te}$ Whanganui a Tara did not progress to the plans of the New Zealand Company and the proposed City of Britannia. Unseasonal (typical) weather and flooding (2 March 1840) was followed by a severe fire (which destroyed 15 raupō houses) and then followed by an earthquake at $5.00 \mathrm{am}$ on the morning of 26 May 1840. A further 24 earthquakes occurred in the district between 1849 and 1845. This all occurred despite the claim of the Company that earthquakes were unknown in New Zealand or were a "one-off" event. ${ }^{8}$ As noted by Eiby in 1970:

The New Zealand Company remained sensitive about this kind of thing [earthquakes] to the end of its days, and its reports of natural disasters (when it couldn't ignore them altogether) are full of traps for the

\footnotetext{
${ }^{6}$ Cochran "Styles of Sham" pp 107-108.

${ }^{7}$ Cochran "Styles of Sham" p 108.

${ }^{8}$ Grayland New Zealand Disasters p 16.
} 
conscientious historian. ${ }^{9}$

Following the shift from Petone to Thorndon in April 1840 and the arrival of additional migrant ships and supplies, building activity accelerated. Charles Heaphy, draughtsman for the Company, estimated that, in November 1841, 195 wooden and brick buildings had been constructed in Wellington with 250 Māori dwellings. ${ }^{10}$ There were also a number of raupō and clay buildings. Ensign Best, on 5 June 1840 for example, described in his journal the wattle and daub Government House at Wellington with interior timber framing. ${ }^{11}$

Bricks had been produced locally since mid1840 and four brickworks were in operation by $1844 .{ }^{12}$ While brick building increased in Wellington after a fire in 1842 when "more than 40 raupo and timber houses were destroyed,"13 the majority of Wellington buildings were timber-framed and weatherboard buildings - giving an overall impression to any visitor of a wooden town. ${ }^{14}$

${ }^{9}$ Eiby "Shaking down in Wellington" p 36.

${ }^{10}$ McGill The Pioneers of Port Nicholson p 33.

${ }^{11}$ Shaw New Zealand Architecture p 15.

${ }_{12}$ Cochran "Styles of Sham" p 108.

${ }^{13}$ Salmond Old New Zealand Houses p 47.

${ }^{14}$ Angas Savage Life and Scenes in Australia and New
Heaphy, writing in 1842 for an English audience, thought that the dominance of timber buildings in Wellington was a consequence of the lack of quality stone in the district and the influence of earthquakes. He also "downplayed" the threat of earthquakes on the new settlement:

Few brick houses have yet to be built in Wellington: partly in consequence of the scarcity of material and partly from fear of the effects of earthquakes. I do not imagine that the earthquakes will prove of much annoyance to the settlers, as from what can be learnt, it appears that the shocks are never very violent. One shock that occurred soon after the completion of a large brick house in Wellington did not do any injury to it, or to any other brickwork. It would, however, be well to build all brick houses substantially; and in their construction much timber should be used, which would materially strengthen and bind the walls. ${ }^{15}$

While the experience of earthquakes influenced the dominance of timber and raupō buildings, it appears that the more substantial drivers were the practicality of using local and cheap building materials, the

Zealand $\mathrm{p}$ 232. Nigel Isaacs provides building construction statistics for Auckland between 1842 and 1852 which provides a summary of stone/brick, wood and raupō buildings (Isaacs "Early New Zealand Building Codes" p 9). The author has not been able to identify similar statistics for Wellington.

${ }^{15}$ Heaphy Narrative of a Residence in New Zealand p 87. influence of Māori building practices, ${ }^{16}$ and, considering that many of the Company settlers were from Kent and Cornwall, the introduction of English timber weatherboarding which was popular in the 1830s. ${ }^{17}$

\section{8}

In 1848, Wellington's population was about 4,400 persons including the Hutt Valley, Porirua and the Kāpiti Coast. ${ }^{18}$ This population experienced the Marlborough earthquake when on 16 October 1848 at 1.40 am the Awatere Fault ruptured releasing a Mw 7.8 earthquake. ${ }^{19}$ The earthquake involved a large number of major aftershocks until 24 October 1848 and continued until October 1849. The earthquake was felt at a level of MM8 at Wellington. ${ }^{20}$

Severe damage occurred from continual

${ }^{16}$ Shaw New Zealand Architecture p 14.

17 Toomath Built in New Zealand p 21; Yska Wellington Biography of a City p 20.

18 "Wellington - Population - 1847" p 3.

${ }^{19} \mathrm{Mw}$ or Moment Magnitude Scale or Richter Scale is a measure of the quantitative measure of the size of the earthquake at its source. It is a base-10 logarithmic scale. "The Richter Magnitude Scale" unpaginated.

${ }^{20} \mathrm{MM}$ or Mercalli Intensity Scale is a measure of the severity of earthquake shaking using a descriptive scale. "The Modified Mercalli Intensity Scale" n.p. 
aftershocks, especially the earthquake of 17 October 1848 which occurred at 3.40 pm. ${ }^{21}$ Loss of life resulted when Barrack MasterSergeant Lovell and his two young children were walking down Farish Street (now Victoria Street) at the time of the quake and were buried by falling bricks from the collapsing walls of Fitzherbert's Store. ${ }^{22}$ The aftershocks were also a threat to workers repairing damage from the first earthquake, such as John Plimmer who nearly died fixing a brick store damaged by the first quake. ${ }^{23}$

Following the earthquakes, a Board of Inquiry was formed consisting of Robert Park, Henry St Hill and Captain Thomas Collinson. The Report of the Board Inquiry provides an account of damage to masonry and clay buildings and chimneys. ${ }^{24}$ A total of 49 buildings were reported as damaged by the earthquakes. Of these, 20 were brick buildings, 17 were of clay construction, 10 were a brick and clay combination and two were timber-framed. The two timber-framed buildings were the Union Bank of Australia

${ }^{21}$ Grapes The Visitation p 36.

${ }^{22}$ Grayland New Zealand Disasters p 14.

${ }^{23}$ Grapes The Visitation p 35.

24 "No. 25. Captain T.B. Collinson, R.E. to the Hon. the Colonial Secretary" pp 176-177. where damage was limited to a brick safe within the building and the Messrs Bethune and Hunter building was slightly damaged from falling store boxes. ${ }^{25}$ It reported that all "almost every chimney in the town, has been broken down close to the roof." 26

Despite the performance of timber houses which mostly survived the earthquake without damage (except for loss of chimneys), the Board of Inquiry did not wholly support the construction of new timber buildings. Instead it focused on the need to improve the construction of brick buildings to safeguard against fires. It considered that the brick buildings were largely damaged because of lack of support of bond-timbers and with mortar consisting of lime and clay (instead of lime and sand). ${ }^{27}$ It recommended new timber-supported masonry buildings:

The building we recommend for the above object, and for greater security against fire than a weather-boarded house, is a strong wooden frame upon a brick foundation, filled in with brick-nogging laid in mortar and covered outside with strong laths and plaster, and

${ }^{25}$ Grapes The Visitation pp 177-182

26 "No. 25. Captain T.B. Collinson, R.E. to the Hon. the Colonial Secretary" p 176.

27 "No. 25. Captain T.B. Collinson, R.E. to the Hon. the Colonial Secretary" p 177. inside with boards or plaster. ${ }^{28}$

Acknowledging, however, the timber building preference of most of the population, the Board recommended greater separation between buildings:

But as it is probable that there will be always a great many houses in the town built entirely of wood, we recommend it to the consideration of the inhabitants that all future wooden houses should be separated from each other as much as possible, both as a security against fire, and because the action of a shock is sometimes of an undulating kind, that will take more effect on a continuous line of buildings than on several detached small ones. ${ }^{29}$

As indicated, the Board considered one of the primary reasons for masonry building failure was the quality of the mortar. This reason was often quoted after the earthquakes to explain earthquake damage and also to "play down" the threat of earthquakes in the settlement. From a layperson's perspective, Charlotte Godley (wife of John Robert Godley and who stayed in Wellington for six months in 1850 before welcoming the arrival of the Canterbury Association Settlement), wrote in

28 "No. 25. Captain T.B. Collinson, R.E. to the Hon. the Colonial Secretary" p 177.

29 "No. 25. Captain T.B. Collinson, R.E. to the Hon. the Colonial Secretary" p 177. 
her Letters from Early New Zealand about the 1848 earthquake:

Almost all the brick edifices went then, including the Hospital, and almost all the chimneys are of brick, they too nearly all came down or cracked. But then it is only fair to say that hardly any mortar has been used until lately, and sand and water is not very sticky. ${ }^{30}$

Godley later wrote, on 12 August 1850, that weatherboard buildings are the "only thing that successfully stands through earthquakes." 31

The 1848 earthquake did damage Wellington's masonry buildings and strengthened the dominance of timber buildings in the fledging settler town. However, there was also a strong view that much damage was a result of masonry buildings with insufficient quality mortar. This view was reflected in the third report of Lieutenant-Governor Eyre to Sir George Grey which, in summary, considered that there were four primary lessons from the disaster:

First, such convulsions appear to be rare ... Secondly the worst shocks have not been the first, and thus a timely warning has been given to quit brick or other dangerous buildings, and little loss of life has ensured. Thirdly, not

${ }^{30}$ Letters from Early New Zealand p 41.

${ }^{31}$ Letters from Early New Zealand $\mathrm{p} 87$. a single wooden building has been destroyed or, as far as I am aware, even injured. Fourthly, there is no doubt whatever that not a single brick building in the town has been really well and properly built. ${ }^{32}$

\section{Surviving pre-1848 buildings today}

While only a small number of buildings were damaged and demolished as a result of the 1848 earthquakes, only a few survivors of this period remain standing today. Two archaeological sites dating from the pre-1848 era that involve structures are the Te Aro Pa foundations on Taranaki Street and Paremata Barracks, Porirua. Paremata Barracks was built by the colonial government in 1846 for the Porirua military operations against Ngāti Toa Rangatira and their allies. Built on a former Māori settlement and burial site, it was a two-storey structure with towers. It was constructed of local stones with poor mortar of beach sand/gravel. ${ }^{33}$ Damage in both the 1848 and 1855 earthquakes has been attributed to violation of wāhi tapu.

Taylor-Stace Cottage at Pāuatahanui was possibly built in 1847 as the residence of

32 Third Report of Lieutenant-Governor Eyre to Sir George Grey, 29 October 1847, quoted Grapes The Visitation p 88.

${ }^{33}$ Bowman, Johnston \& O'Keeffe "Paremata Barracks Conservation Plan"
William and Anne Taylor. ${ }^{34}$ The cottage is a timber-framed structure with the exterior walls sheathed in plain weatherboards on the back or south wing, and rusticated weatherboards on the front or north wing. It has a gable roof sheathed in corrugated iron. The front two rooms of the cottage are a 1906 addition built by David Greig. ${ }^{35}$

Homewood in Karori was also built in 1847 as residence of Henry Samuel Chapman, first Judge of the Supreme Court. ${ }^{36}$ The Chapman diaries record in some detail the construction of the house and daily life of the Chapmans, noting that they shifted into the house on 24 April 1847 and that the house was substantially enlarged in 1903 while retaining the 1847 cottage as servant's quarters. It is the L-shaped wing on the south-west elevation of the house that is considered to date from April 1847 - having a two storeyed steeplypitched roof and low ceiling studs.

Collet House in Petone dates from 1848 and was the home of Henry and Eliza Collet. The

${ }^{34}$ Carman Tawa Flat and the Old Porirua Road p 96.

${ }^{35}$ Cochran, Chris Taylor-Stace Cottage Pauatahanui, Conservation Report, Wellington: Works Consultancy Services, 1994; Taylor-Stace Cottage, New Zealand Historic Places Trust file, HP 12013-277.

${ }^{36}$ Smedley Homewood and its Families pp 22-23. 
Collets arrived in Wellington on the ship London in 1841. After setting up a carpentry business in Te Aro, the couple moved to Petone in 1847.37 Henry Collet established himself as a wheelwright, servicing carts and coaches travelling on the main road leading north from Wellington. By 1848 the Collets had constructed a simple four roomed, twostorey dwelling from pit-sawn weatherboards on land adjacent to the road. Collet House has had substantial alterations with extensions between 1874 and 1890 and a bungalow-style roof added in $1945 .{ }^{38}$

Other potential pre-1848 candidates are Papakōwhai Homestead, Porirua, and Fernhill at 15 Fern Hill Terrace, Wadestown. The earliest part of Fernhill possibly dates from the mid-1840s when the owner of the property was Charles Pharazyn. ${ }^{39}$ The bulk of the house, however, was constructed in the early 1860s for Samuel Grimstone. The rear part of Papakōwhai Homestead is thought to date from 1848 when the Bowler family farmed the area. In 1855 the house was purchased by Anthony Wall, who constructed a large

${ }^{37}$ Butterworth Petone $\mathrm{p} 67$.

${ }^{38}$ Collet House, New Zealand Heritage Places Trust file, HP 12013-486.

${ }^{39}$ Parr "Early Fernhill" p 19.

\section{Victoria addition in $1888 .{ }^{40}$}

Bethune and Hunter's Building on Bond Street, dating from 1844, was referred to in the Board of Inquiry Report above, and survived until the late 1950s when it was demolished for new development. ${ }^{41}$

Outside of Wellington, St John's Church, Wakefield dates from 1846 and Rangiātea Church, Ōtaki, was built between 1848 and 1951. Prior to its destruction by arson in 1995, Rangiātea was hailed as symbolic of Māori and European spiritual and building traditions. ${ }^{42}$ There is also a surviving "stud and mud" cottage at Robin Hood Bay in Marlborough which may possibly date from $1848 .{ }^{43}$

\section{5}

By 1855, Wellington's population had risen to 5,966, including Porirua and the Hutt Valley. ${ }^{44}$ Timber-framed and weatherboard buildings

${ }^{40}$ Kay \& Kay Anthony Wall, Settler of Porirua pp 140-141.

${ }^{41}$ Alexander Historic Wellington pp 9-10.

${ }^{42}$ Shaw New Zealand Architecture p 22.

${ }^{43}$ Cochran, Chris Cobb Cottage, Robin Hood Bay

Marlborough, Wellington: Ministry for Works and

Development, April 1983.

${ }^{44}$ New Zealand Government Gazette p. 109. again dominated Wellington township with most masonry buildings damaged in 1848 rebuilt in timber. ${ }^{45}$ Chimneys had also been secured by iron braces. ${ }^{46}$ A noticeable exception was Baron Alsdorff's hotel which was rebuilt in brick following the 1848 earthquake. ${ }^{47}$ Charles Rooking Carter, a builder who arrived in Wellington in 1850, described the wooden town of Wellington as having a "scattered appearance" with the commercial town "not remarkable for their large dimensions, or their relationship to any particular order of architecture." 48 With regard to the dwellings, Carter observed:

When on shore I found that the houses of the majority of inhabitants, in the rest of the town, were in a style of genuine simplicity - a long, narrow, but very large box: the sides fronting the streets were about 8 feet in height and from 20 to 24 feet in length; they had a door in the middle, and a window about $5 \mathrm{ft}$. by $3 \mathrm{ft}$. on each side of the door. The house was divided into two rooms, one on the right the other on the left, and was frequently supplemented with the fashionable and useful lean-to sometimes constructed at one end, but oftener in the rear of these truly convenient and comfortable colonial cottages which being generally painted white, looked

\footnotetext{
${ }^{45}$ Drury Remark Book p 92.

${ }^{46}$ Drury Remark Book p 92.

${ }^{47}$ Drury Remark Book p 92.

${ }^{48}$ Carter Life and Recollections of a New Zealand Colonist $\mathrm{p}$
} 
neat, clean and fresh. ${ }^{49}$

While timber-framed/weatherboard buildings dominated, there were still a number of raupō and clay buildings in Wellington, especially within Māori settlements. ${ }^{50}$ Raupō buildings had been the subject of the New Zealand's first building tax legislation with the "Raupo Houses Ordinance" passed by the Legislative Council back in 1842. ${ }^{51}$ This original Auckland Provincial Council legislation was in response to a "disastrous fire which started in a bake house with a thatched roof on the night of 9 November 1842" and was extended to Wellington in $1843 .{ }^{52}$

${ }^{49}$ Carter Life and Recollections of a New Zealand Colonist $\mathrm{p}$ 7; Carter wrote that he acquired the damaged Council Chamber building following the 1855 earthquake and preserved it (as a ruin?). He stated it was "one of the oldest, if not the oldest public building in Wellington, a certain historical interest clings to it; and as from sheer decay it must soon pass away along with the old Colonists who have witnessed its creation and vicissitudes ..." Carter Life and Recollections of a New Zealand Colonist pp 6-7.

${ }^{50}$ Hodgson Colonial Capital Wellington 1865-1910 p 9; For example, the Native Secretary, H. Tacy Kemp, Survey of Wellington pā in 1850 recorded that at Pitone Pa there was 1 chapel, 3 weatherboard houses and 35 raupo huts. Butterworth Petone A History p 77.

${ }^{51}$ Isaacs "Early New Zealand Building Codes" p 8.

${ }^{52}$ Isaacs "Early New Zealand Building Codes" p 8. Note, the "Raupo Houses Ordinance" and other related raupō
Earthquakes had continued in Wellington after October 1849. As recorded by Charlotte Godley during her six-month Wellington stay in 1850, no less than eight earthquakes were felt between 7 May and 27 July 1850. Carter also recorded minor earthquakes in 1851, his first experience of a "slight shock" on 5 January $1851 . .^{53}$ While some of these earthquakes were loud enough to be mistaken for volcanic eruption, they caused little or no damage. This changed when New Zealand's most powerful recorded earthquake occurred at $9.00 \mathrm{pm}$ in the evening on 23 January 1855. The magnitude Mw 8.3 Wairarapa earthquake was felt at MM10 in Wellington. ${ }^{54}$ This time seven to nine people were killed and five injured. Aftershocks continued until 10 October 1855.

A Commission was established to report about the earthquake to the Provincial

legislation was considered by Māori to be a way of removing Māori buildings (and removing Māori settlements) from within towns and has been claimed as a Breach of the Treaty of Waitangi as part of claims to the Waitangi Tribunal.

${ }^{53}$ Carter Life and Recollections of a New Zealand Colonist $\mathrm{p}$ 11.

${ }^{54}$ MM10 at Wellington: Very destructive, many

buildings damaged, most weak buildings destroyed. "M 8.2-8.3, Wairarapa, 23 January 1855" n.p.
Government. The Commission, consisting of C Mills and Carter, completed its report on 6 October 1855. Much of the report repeated the findings from the earlier 1848 report - that brick and stone buildings were unsafe without solid timber support and that well-built buildings with solid foundations suffered little damage. However, some 15 years had now passed since the founding of the Wellington settlement and much of the early building timber work had already deteriorated and parts of the town had expanded onto poorer quality low-level land:

In those parts of town the most damage occurred, namely dilapidated buildings and defective foundations; buildings erected on loose gravelly or swampy foundations; buildings with ground plates partially or entirely decayed or destitute of braces - have suffered severely while both houses and stores where the timbers were sound and the foundations good, have escaped without almost any injury. ${ }^{55}$

Again, as in 1848, the 1855 Commission was also concerned about fire risk:

"Had Earthquakes been their only study, buildings entirely constructed of wood would have been recommended, for sound and well-constructed wooden houses receive no damage from earthquakes, but timber being very combustible, and subject to rapid decay, it

\footnotetext{
${ }^{55}$ Grapes Magnitude Eight Plus p 196.
} 
becomes a matter of urgent importance to a City like Wellington, daily increasing in size, and the buildings once detached now being united in block, or in street line, to be provided with building materials of such a nature as will combine 3 properties, viz. - strength, durability, and incombustibility." 56

Essentially, the Commission aimed that future buildings should be low level, fire resistant, earthquake resistant structures to be hopefully maintained in good condition. The Wellington Independent reflected this by stating:

We can dispense in future with high massive buildings, and can make very pretty and comfortable the city of Wellington, even though our houses should be one story high, and the material used in their construction, be nothing more substantial than painted boards. ${ }^{57}$

\section{Surviving pre-1855 buildings today}

While Taylor-Stace Cottage, Papakōwhai Homestead, Collet House and Homewood survived both the 1848 and 1855 earthquakes, there are not a large number of pre- 1855 survivors existing today. One of the few is Christ Church in Taitā. Christ Church which opened for service on 1 January 1854. It was constructed by Sidney Hirst of heart tōtara, pit

${ }^{56}$ Mills \& Carter "Report of the Commission" (1855) quoted, Grapes Magnitude Eight Plus Appendix 3, p 195. 57 "The Wellington Independent: Saturday, February 10, 1855 " p 3. sawn from local forest and hauled to the site on bullock drays. Another possible candidate is Harrison Cottage at Glenside which may date to $1855 .{ }^{58}$

While not pre-1855, the St Joseph's Providence Porch, St Mary's College, at 15 Guildford Terrace, is linked to Wellington's earthquake story. Located within the grounds of the present-day St Mary's College in Thorndon, the shelter porch is associated with the former St Joseph's Providence, a charity school that was established in 1852 with the intention of providing education for Māori girls. It was a timber-framed two-storey building with eighteen bedrooms. ${ }^{59}$ Closely aligned with the Sisters of Mercy, the Providence played both an important role in the history of Roman Catholicism and education in Wellington. The 1852 building was demolished in 1890 and further demolition occurred in 1976. The porch, which dates from 1869, was retained as a reminder to the hardship and sacrifices endured by the Sisters of Mercy in their efforts

${ }^{58}$ Secker "Harrison's Cottage preserves the past" p 28. Another possible early survivor could be Brown's

Cottage, Main Road, Tawa, which may date from 18541855. Further research would be required, however, to identify the location and history of this dwelling.

${ }^{59}$ Redwood Sketch of the work of the Catholic Church p 14. to assist the early community of Wellington. ${ }^{60}$ These hardships have been commemorated every year since 8 December 1855 which was the day proclaimed by Archbishop Redwood as the Dogma of the Immaculate Conception Proclaimed in Wellington - to preserve the city from earthquakes. ${ }^{61}$

Outside of Wellington, Dicky Sayer's Slab Whare, Dalefield Road, Carterton, was built about 1854. It is a slab and batten construction with floorboards on the ground. David Kernohan notes that this building is possibly one of the last remaining examples of this type in New Zealand and is subject to severe neglect and deterioration. ${ }^{62}$ Spinks Cottage at St John's on Willis Street could also be a potential 1855 survivor as it was built sometime between 1854 and 1863. ${ }^{63}$

All the pre-1855 survivors are timber-framedweatherboard buildings. They were all relatively "new" buildings at the time of the 1848-1855 earthquakes and the author can only assume that the buildings had not

${ }^{60}$ Flannigan Like a mustard seed pp 35-37, 83-86.

${ }^{61}$ Redwood Sketch of the work of the Catholic Church $\mathrm{p} 14$.

${ }^{62}$ Kernohan Wairarapa Buildings p 47.

${ }^{63}$ Burgess \& Treep Architects "Spinks Cottage Dixon Street, Wellington" 
suffered sufficient physical deterioration to cause any damage. The author also assumes that damage was not caused by liquefaction. The primary source of damage would have been in cracking and falling chimneys as recorded by Chapman at Homewood.

The New Zealand Company scheme for Wellington involved 1,100 town acre sections and 100 -acre country sections. ${ }^{64}$ All the potential pre-1855 survivors (Homewood, Taylor-Stace, Collet House, Papakōwhai Homestead, Fern Hill and Christ Church) were built on the large 100-acre country sections providing safe distance from other buildings and mitigating against fire risk and earthquake-induced pounding from shared walls. While subdivision since 1855 has broken up these large original sections, the buildings remain separated to a degree from the surrounding now suburban or semi-rural environment.

Except for the pre-1855 churches, the survivors have been substantially altered and modified for domestic or other purposes. The need to maintain buildings, both in terms of use and fabric, requires an adaptive approach

${ }^{64}$ McClean "Power/Knowledge and Space" p 74. to heritage that recognises change is constant and can be positive for the survival of heritage values. As Cochran states this requires a "sensible conservation" approach:

The timber buildings that by good fortune remain today from the early period of colonisation, whether cottage, church or office building, are now valuable cultural objects. They are still able, with sensible conservation, to fulfil a socially useful purpose, which is the best way of ensuring their survival for the understanding and enjoyment of future generations. ${ }^{65}$

The "trick" of sensible conservation is to continue to ensure a place serves a socially useful purpose but also retains sufficient heritage fabric over a long period of time. Unfortunately, with many of the pre-1855 survivors, much original fabric has been lost by alterations and additions. However, a comparison can be made between a cottage such as Taylor-Stace and with Dicky Sayer's Slab Whare in the Wairarapa. While TaylorStace may have little "original" fabric from 1848 , it has retained a purpose as a residence, museum and most recently a spa business. Meanwhile, Dicky Sayer's Slab Whare appears to be entirely "original', is perceived to serve no useful purpose for successive land owners - and the building is now subject to severe

${ }^{65}$ Cochran "Styles of Sham" pp 107-108. deterioration.

\section{Conclusion}

Earthquakes are often remembered as "oneoff" events associated with a particular year or date. The early Wellington settler experience of earthquakes, however, began soon after the colonists arrived in 1840 and appeared to continue largely until late 1855 with many minor shocks and the major earthquakes of 1848 and 1855.

While Wellington's colonial timber buildings style was influenced by the earthquakes, it was not, however, wholly earthquake-driven. It was a result of practical economy of using local, relatively cheap forest resources and the lack of a quality local building stone. It also carried on timber building traditions of England (especially by the settlers from Kent) and was influenced by Māori building methods and techniques. Timber buildings were the dominant building method in Wellington by the early 1840s - well before the 1848 earthquake. The earthquakes of 1848 and 1855 reinforced the primacy of timber despite views that masonry buildings provided the best safeguard against a bigger threat - fire. 
Buildings constructed before 1855 provide a unique insight into building history and technique and can help inform current approaches to building regulation following the Canterbury earthquakes of 2010-12. While many hundreds of buildings did survive the 1848-49 and 1855 earthquakes, few of these buildings survive today as a consequence of urban expansion, neglect or other events such as fire. Homewood, Taylor-Stace Cottage, Collet House (and possibly parts of Papakōwhai Homestead and Fern Hill) are some of the survivors of the 1848 earthquake. They are all timber-framed/weatherboard residential dwellings that have been substantially modified for domestic or other purposes. They are all well-maintained buildings located within suburban or semirural settings separated from other dwellings which has mitigated against the threat of fire and earthquake damage from shared walls. These are joined by the survivors of the 1855 earthquake - Christ Church and possibly Harrison Cottage at Glenside.

Heritage values are about the values that people associate with a place. Early in Wellington's settler history, timber buildings were viewed as safe and secure buildings that could survive if they could be maintained and protected from fire and floods. The timber buildings of Wellington, therefore, became perceived as heritage - of value to the city. The earthquakes of 1848 and 1855 reinforced this perception of timber buildings and influenced a new "generation" of larger timber buildings for public purpose during the 1860s and 1870s such as Old St Paul's (1866), Government Buildings (1876) and St Peter's on Willis Street (1879). All of the 1848 and 1855 survivors and the post-quake buildings should have a role in helping to ensure that earthquake experience does not fade from public memory and this heritage can influence decisions about new building standards and design today. 


\section{REFERENCES}

Alexander, John H. Historic Wellington, Wellington: AH \& AW Reed, 1959.

Angas, G.F. Savage Life and Scenes in Australia and New Zealand London: Smith, Elder \& Co, 1847.

Bowman, Ian, Warwick Johnston and Mary O'Keeffe "Paremata Barracks Conservation Plan" New Zealand Historic Places Trust, March 2005.

Burgess and Treep Architects "Spinks Cottage Dixon Street, Wellington" Conservation Plan, 2005.

Butterworth, Susan Petone; A History, Petone: Petone Borough Council,1988.

Carman, Arthur Tawa Flat and the Old Porirua Road, Wellington: A.H. Carman, 1956.

Carter, Charles Rooking Life and Recollections of a New Zealand Colonist, London: Madley Ltd, 1866. Vol III.

Cochran, Chris Cobb Cottage, Robin Hood Bay Marlborough, Wellington: Ministry for Works and Development, April 1983.

Cochran, Chris "Styles of Sham and Genuine Simplicity: Timber Buildings in Wellington to 1880" The Making of Wellington 1800-1914, ed. David Hamer \& Roberta Nicholls Wellington: Victoria University Press, 1990 pp 107-128.

Cochran, Chris Taylor-Stace Cottage Pauatahanui, Conservation Report, Wellington: Works Consultancy Services, 1994.

Collet House, NZHPT file, HP 12013-486.

Drury, Commander Remark Book, H.M.S Pandora, 25 January 1855. Great Britain Parliamentary Papers, v. 10, 1854-1860.

Eiby, G.A "Shaking down in Wellington" Wellington Prospect ed. N.L. McLeod \& B.H. Farland Trentham: Wright \& Carman Ltd, 1970.

An Epitome of Official Documents Relative to Native Affairs and Land Purchases in the North Island of New Zealand ed. H. Hanson Turton
Wellington: George Didsbury, 1883

http://nzetc.victoria.ac.nz/tm/scholarly/tei-TurEpit.html.

Flannigan, Mary de Porres Like a mustard seed: the History of the Sisters of Mercy in Wellington, Wellington: Sisters of Mercy, 2009.

Grapes, Rodney Magnitude Eight Plus, New Zealand's Biggest Earthquake, Wellington: Victoria University Press, 2000.

Grapes, Rodney The Visitation, The Earthquakes of 1848 and the Destruction of Wellington, Wellington: Victoria University Press, 2011.

Grayland, E.C. New Zealand Disasters Wellington: AH \& AW Reed, 1957.

Hamer, David New Towns in the New World New York: Columbia University Press, 1990.

Heaphy, Charles Narrative of a Residence in New Zealand, London: Smith, Elder \& Co, 1842.

Hodgson, Terence Colonial Capital Wellington 1865-1910, Auckland: Random Century, 1990

Isaacs, Nigel "Early New Zealand Building Codes" CHS Magazine The Magazine of the Construction History Society (December 2011) 90:7-11.

Kay, Barbara \& Kay, Robin Anthony Wall, Settler of Porirua: The Papakowhai story, Porirua: Organising Committee for Wall Family 150th Reunion, 1996.

Kernohan, David Wairarapa Buildings Two centuries of New Zealand architecture, Masterton: Wairarapa Archive, 2003.

Letters from Early New Zealand by Charlotte Godley ed. John R Godley Christchurch: Whitcombe \& Tombs Ltd, 1951.

"M 8.2-8.3, Wairarapa, 23 January 1855" GeoNet http://info.geonet.org.nz/display/quake/M+8.2+$+8.3 \% 2 \mathrm{C}+$ Wairarapa $\% 2 \mathrm{C}+23+$ January+1855

McClean, Robert "Power/Knowledge and Space: The Creation and Alienation of the "Reserve" at Porirua: a thesis presented in partial 
fulfillment of the requirements for the degree of Master of Philosophy in Geography at Massey University" Palmerston North: MPhil Thesis, Massey University, 1996.

McGill, David Lower Hutt The First Garden City Lower Hutt City Council, 1991.

McGill, David The Pioneers of Port Nicholson, Wellington: AH \& AW Reed, 1984.

"The Modified Mercalli Intensity Scale" GNS Science/Te Pū Ao http://www.gns.cri.nz/Home/Learning/Science-

Topics/Earthquakes/Monitoring-Earthquakes/Other-earthquakequestions/What-is-the-difference-between-Magnitude-and-

Intensity/The-Modified-Mercalli-Intensity-Scale

New Zealand Historic Places "Register of Historic Places"

http://www.historic.org.nz/TheRegister.aspx

"No. 25. Captain T.B. Collinson, R.E. to the Hon. the Colonial Secretary: Official Report on the Earthquakes of October, 1848" (Wellington, 21st November, 1848) Turton, Hanson An Epitome of Official Documents Relative to Native Affairs and Land Purchases in the North Island of New Zealand, Wellington: George Didsbury, 1883 pp 176-177. URL: http://nzetc.victoria.ac.nz/tm/scholarly/tei-TurEpit.html

Parr, Nora "Early Fernhill" The Onslow Historian (1981) 11(1):19-20, 23.

Petre, Hon. Henry An Account of the Settlements of the New Zealand Company London: Smith, Elder \& Co 1842.

Redwood, Archbishop Sketch of the work of the Catholic Church for the last Half-Century, Wellington: Lyon \& Blair, 1887.

"The Richter Magnitude Scale" GNS Science/Te Pū Ao http://www.gns.cri.nz/Home/Learning/ScienceTopics/Earthquakes/Monitoring-Earthquakes/Other-earthquakequestions/What-is-the-difference-between-Magnitude-andIntensity/The-Richter-Magnitude-Scale
Salmond, Jeremy Old New Zealand Houses 1800-1940, Auckland: Reed, 1986.

Secker, W.H. "Harrison's Cottage preserves the past" Kapi-Mana News (24 August 1976), p 28. (also http://www.tawahistory.wellington.net.nz/projects/secker_articles.ht $\mathrm{ml})$

Shaw, Peter New Zealand Architecture From Polynesian Beginnings to 1990, Auckland: Hodder \& Stoughton, 1991.

Smedley, Beryl Homewood and its Families, A Story of Wellington, Wellington: Mallinson Rendel Ltd, 1980.

Stacpoole, John Colonial Architecture Wellington: AH \& AW Reed, 1976.

Taylor-Stace Cottage, New Zealand Historic Places Trust file, HP 12013277.

Toomath, William Built in New Zealand The Houses we Live in, Auckland: Harper Collins, 1996.

Townend, John, Langridge Rob and Jones, Andrew, Proceedings from the 1855 Wairarapa Earthquake Symposium 150 years of thinking about magnitude 8+ earthquakes and seismic hazard in New Zealand Wellington: Greater Wellington Regional Council, September 2005.

"The Wellington Independent: Saturday, February 10, 1855" Wellington Independent (10 February 1855):3.

"Wellington - Population - 1847" Wellington Independent (1 January 1848):3.

Yska, Redmer Wellington Biography of a City Wellington: Reed, 2006. 